\title{
高枝化官能化聚合物的合成方法学
}

\author{
李婷婷, 马红卫, 魏志勇, 郭方, 申凯华, 牛慧, 李杨 \\ 大连理工大学化工与环境生命学部高分子材料系, 精细化工国家重点实验室, 大连 116024 \\ * 联系人, E-mail: liyang@dlut.edu.cn
}

2015-10-15 收稿, 2015-12-22 修回, 2016-01-27 接受, 2016-04-05 网络版发表

国家重点基础研究发展计划(2015CB654701)、国家自然科学基金(U1462126, U1508204, 21404019)和中国博士后基金(2014M550154)资助

\begin{abstract}
摘要结构化、功能化、集成化是合成橡胶及弹性体实现高性能化的有效手段, 活性阴离子聚合是高分子链实 现高枝化和官能化的有效手段。高枝化聚合物具有独特的结构和性能, 近年来已在聚合物材料应用中脱颖而出, 并且逐渐成为高分子化学领域的研究热点. 基于研究现状, 本文总结了高枝化官能化聚合物合成方法学的研究进 展. 采用共聚合方法、基团转换方法、硅氢加成方法、点击化学方法合成的高枝化官能化聚合物，扩展并延伸了 原有聚合物橡胶的性能, 为合成绿色橡胶提供了新思路、新方法. 功能聚合物的高枝化拓扑结构与性能之间的关 联规律也为绿色橡胶的设计开发提供了依据和基础.
\end{abstract}

关键词高枝化聚合物, 官能化, 阴离子聚合, 合成方法学

高性能化是合成橡胶及弹性体发展的必然方向, 是实现合成橡胶及弹性体产品结构调整、产品升级换 代的必由之路. 合成橡胶及弹性体的高性能化对于 提升合成橡胶及弹性体行业的技术水平, 以及增强 合成橡胶及弹性体的市场竞争力具有重要意义. 结 构化、功能化、集成化是实现合成橡胶及弹性体高性 能化的有效手段. 溶聚丁苯橡胶是实现合成橡胶及 弹性体高性能化的一个典型实施例. 以普通的溶聚 丁苯橡胶为基础, 第 1 代卤代硅烷偶联的星形溶聚丁 苯橡胶极大地改善了溶聚丁苯橡胶的加工性能和冷 流性能. 四氯化锡偶联的第 2 代锡偶联星形溶聚丁苯 橡胶, 有效地降低了轮胎的滚动阻力、内耗生热, 实 现了安全节能的目标. 高分子结构从线形到星形的 设计, 有效地完成了结构的优化, 锡偶联溶聚丁苯橡 胶是功能化溶聚丁苯橡胶的倠形. 集成化是指以釜 内原位聚合的方法, 将所需橡胶键合到一条聚合物 链上, 取代传统橡胶开炼或密炼共混并用的加工方 法, 将各种橡胶特性集于一身, 呈正协同效应. 集成
橡胶SIBR 是以溶聚丁苯为基础进行集成化研究的典 型实施例，可视为第 3 代溶聚丁苯橡胶，它是通过共 聚合方法将丁苯橡胶、聚丁二烯橡胶、聚异戊二烯橡 胶、丁戊橡胶键合到同一条聚合物链上，集4种合成 橡胶的优异性能于一身. 集成橡胶SIBR不仅实现了 取代高耗能的传统物理混炼并用的方法, 而且有效 地解决了宽温域、宽频带黏弹性能的分子结构设计难 题. 端基官能化溶聚丁苯橡胶是第 4 代溶聚丁苯橡胶, 与此同时也是真正意义上的官能化溶聚丁苯橡胶, 它通过引人端基官能团有效地限制了合成橡胶大分 子链端的自由运动, 减少了摩擦生热, 同时也有利于 改善碳黑的分散性. 但是链端官能化溶聚丁苯橡胶 存在链端有限导致官能化程度较低的问题, 因此为 了更好地改善碳黑分散性以满足高端绿色轮胎用胶 的需求, 第 5 代链中官能化溶聚丁苯橡胶应运而生. 链端、链中多官能化的溶聚丁苯橡胶(超级官能化)同 时解决了减少链端运动摩擦生热和碳黑高分散性的 问题, 得到了合成橡胶及轮胎行业的广泛关注. 高枝

引用格式: 李婷婷, 马红卫, 魏志勇, 等. 高枝化官能化聚合物的合成方法学. 科学通报, 2016, 61: 3304-3314

Li T T, Ma H W, Wei Z Y, et al. Synthesis methodology of dendrigraft functional polymer (in Chinese). Chin Sci Bull, 2016, 61: 3304-3314, doi: 10.1360/N972015-01152 
化溶聚丁苯橡胶 (超级结构化) 具有极佳的力学性能 和加工性能、优异的溶液和流变特性, 同时合成方法 简单、经济、高效, 可望成为新一代高性能溶聚丁苯 橡胶.

活性阴离子聚合是实现高分子链高枝化和官能 化的有效手段, Quirk等人 ${ }^{[1]}$, Hirao等人 ${ }^{[2,3]}$ 和Nikos等 人 $^{[4]}$ 在官能化高分子的研究中取得了较好进展, 高枝 化聚合物近年来作为一种具有独特结构和性能的聚 合物材料, 已在高分子材料的应用中脱颖而出, 逐渐 成为高分子化学领域的研究热点 ${ }^{[5 \sim 7]}$. 本研究组 ${ }^{[8 \sim 11]}$ 从活性阴离子聚合理论和方法出发, 深人系统地开 展了高枝化官能化聚合物的合成方法学研究, 揭示 了高枝化官能化聚合物的复杂拓扑结构与性能之间 的构效关系, 创制了一系列高枝化官能化聚合物, 构 建了相关的合成方法学平台. 本文对国内外近年来 在高枝化官能化合成橡胶及弹性体领域的研究成果 进行了整理总结.

\section{1 高枝化聚合物合成方法研究}

偶联法是实现高枝化聚合物合成的重要手段, 该方法首先通过官能化反应在线形聚合物基体上引 人偶联反应点, 然后与活性阴离子聚合物发生偶联 反应制备梳形枝化聚合物 (G0代高枝化聚合物). 以 此方法不断迭代反应便可达到 G1-G $n$ 代高枝化聚合 物. 偶联法制备的高枝化聚合物具有结构可控、分子 量呈级数增长等特点. Gauthier和Moller ${ }^{[12]}$ 采用氯甲 基化反应向聚苯乙烯链中引人偶联点后, 将其与活 性聚苯乙烯链反应制备了 G0代聚合物, 以此类推, 多次的氯甲基化反应-偶联反应便得到了高代数的高 枝化聚苯乙烯. 通过傅-克酰基化反应将乙酰化官能 才引人聚苯乙烯基质上也是向线形聚苯乙烯链引人 偶联点的一个有效手段, 并可以此为基础合成高枝 化聚苯乙烯 ${ }^{[13]}$. 在高枝化聚丁二烯的合成中, Hempenius等人 ${ }^{[14]}$ 向聚丁二烯链中引人了氯代硅烷 作为偶联点, 实现了与聚丁二烯锂的高效反应. 环氧 基团与阴离子聚合活性中心具有高效的反应活性, 因此多环氧基团化合物是活性阴离子聚合的高效偶 联剂, 近年来被广泛地应用于星形聚合物的合成. Gauthier研究组 ${ }^{[15]}$ 以环氧化聚异戊二烯为偶联点, 与 活性聚异戊二烯锂反应制备了 G0-G2 代高枝化聚异 戊二烯. 本研究组 ${ }^{[16 ~ 22] ~}$ 基于活性阴离子聚合方法, 以创新设计的环氧化液体线形/星形聚丁二烯/异戊二
烯为偶联剂, 以环氧化-偶联反应循环迭代增长的方 法合成了结构新颖的多代高枝化星形梳状聚合物, 构筑了简便高效的高枝化星形梳状聚合物精确合成 方法平台, 并广泛应用于系列化高性能锂系聚合物 的创制, 构建了线形/星形梳状高枝化聚合物、官能化 聚合物、官能化高枝化聚合物以及官能化高枝化聚烯 烃合成方法平台，如图1所示. 采用以上合成方法可 成功制备高枝化星形梳状聚丁二烯，所合成的 G4代 高枝化聚丁二烯分子量高达 1400 万、分子量分布 1.17 、支化度近 $4000^{[16]}$. 该方法亦可直接应用于高枝 化锂系聚合物的合成, 制备高枝化的锂系聚丁二烯 橡胶、锂系异戊橡胶、溶聚丁苯橡胶、溶聚集成橡胶、 苯乙烯-丁二烯-苯乙烯三嵌段热塑性弹性体(SBS)和 苯乙烯-异成二烯-苯乙烯三嵌段热塑性弹性体(SIS) 等, 实现锂系聚合物的高性能化.

本研究组 ${ }^{[23,24]}$ 开展了官能化高枝化聚合物合成 方法的应用研究, 以环氧化液体聚丁二烯、丁苯共聚 物为偶联剂, 成功地合成了高枝化高透明丁苯抗冲 树脂, 从产品到方法构建了知识产权保护链. 与传统 方法合成的丁苯透明抗冲树脂相比, G1 代高枝化高 透明丁苯抗冲树脂 Izod 冲击强度提高 10 倍, 高达 $236.4 \mathrm{~J} / \mathrm{m}$, 试验样条冲击不断, 丁苯抗冲树脂的形态 结构和冲击化曲线如图 2所示 ${ }^{[18]}$. 由此可见, 高枝化 结构不仅能够有效地改善聚合物的加工性能, 而且 能够有效地改善通用材料的物理机械性能. 高枝化 G1代合成方法简单实用、经济高效, 具有广泛的产业 化应用前景.

环氧基团不仅是一种重要的偶联剂, 而且极易 通过官能团转换为羟基、再从羟基出发转换为其他官 能团, 多官能团产物可作为不同聚合反应的多官能 度引发剂, 简单高效地合成多种高枝化聚合物. 环氧 基团转换为差基后, 可作为环内酯、环交酯、环状碳 酸酯等环状单体开环聚合的多官能度引发剂, 合成 诸如线形/星形梳状聚乳酸、聚己内酯、聚碳酸酯等 具有复杂拓扑结构的生物基高分子材料, 本团队基于 该合成方法已开展了较多研究, 研究思路如图3所示.

以线形/星形多羟基聚丁二烯为环内酯开环聚 合引发剂、以 1,8 -二氮杂二环十一碳 - 7 - 烯 (DBU)/1,5,7-三氮杂二环[4.4.0]癸-5-烯(TBD)为催化 剂, 成功地建立了基于无金属引发体系高枝化环内 酯开环聚合物合成方法平台，并成功地合成了高分 子量、窄分布高枝化聚乳酸、高枝化聚成内酯、高枝 


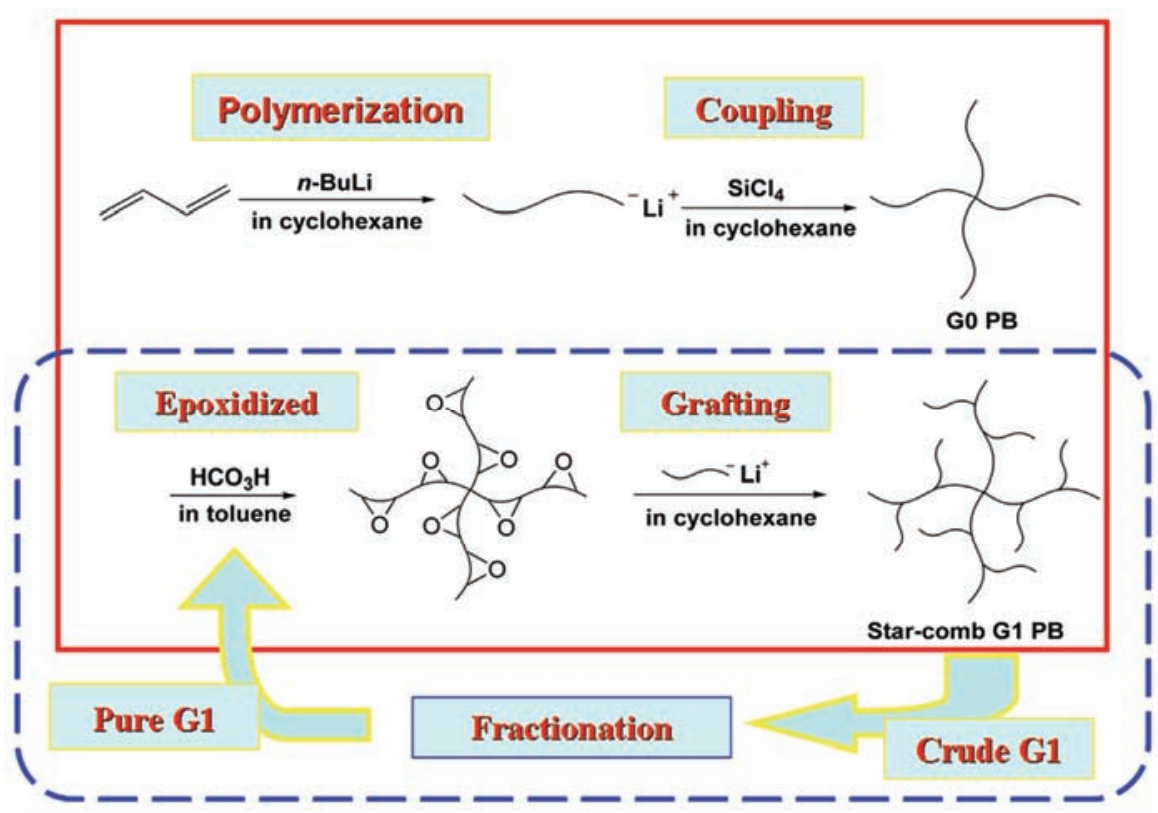

图 1 高枝化聚合物合成方法

Figure 1 Synthesis of dendrigraft polymers

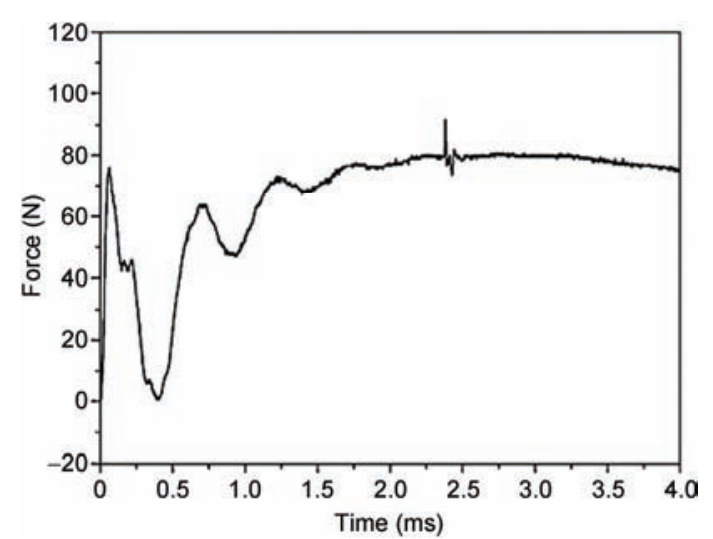

图 2 G1 高枝化高透明丁苯抗冲树脂其冲击化曲线 ${ }^{[18]}$

Figure 2 Impact curves of G1 dendrigraft high transparent butadiene-styrene resins ${ }^{[18]}$

化聚己內酯、高枝化聚碳酸酯等一系列高枝化环内酯 开环均聚物和共聚物, 聚合物具有高枝化、高分子 量、窄分布的特点 ${ }^{[25 ~ 29]}$, 如图4所示. 研究阐明了高 枝化聚乳酸的复杂拓扑结构对结晶性能的影响规律, 其结果表明线形梳状聚乳酸比星形梳状聚乳酸具有 更快的结晶速度.

\section{2 官能化聚合物合成方法研究}

\section{1 共聚合方法合成官能化聚合物}

共聚合是实现功能化最简单有效的方法. 通用
单体，如丁二烯、异戊二烯和苯乙烯，与不同性质的 单体进行共聚合反应, 可实现不同功能性的官能化 弹性体和树脂的制备. Hadjichristidi研究组 ${ }^{[30]}$ 采用亲 水性单体环氧乙烷与亲油性单体丁二烯进行共聚合 反应制备了两亲性共聚物. Watanabe研究组 ${ }^{[31]}$ 采用 含液晶单元的单体与苯乙烯共聚合制备了液晶性官 能化聚合物.

近年来, 本研究组 ${ }^{[32 ~ 37]}$ 深人细致地开展了官能 化单体合成以及共聚合方法制备官能化聚合物的研 究. 官能化单体的研究包括双同官能团 1,1 -二苯基乙 烯(DPE)衍生物(含氮双官能团DPE衍生物、含氧双官 能团DPE衍生物)、双异官能团DPE衍生物(含氧/硅 氢、含氮/硅氢双官能团DPE衍生物)。共聚合方法研 究包括成功地合成了不同数量、不同特性、不同结构 的官能化聚合物. 在共聚合反应动力学的研究中准 确地计算了竞聚率参数, 并利用高真空实验定时采 样, 精确地研究了不同官能团DPE衍生物在共聚物 中的序列分布. 成功地合成了含氮双取代型 1,1-二苯 基乙烯衍生物单体(DPE-2N), 并开展了含氮双取代 型1,1-二苯基乙烯衍生物单体与丁二烯、异成二烯、 苯乙烯共聚合反应规律的研究; 创制了链端链中多 官能团溶聚丁苯橡胶(F-SSBR)，并对含氮双官能团 D P E 衍生物 1, 1 - 双 (4-二甲基氨基苯基) 乙烯 $(D P E-2 N) 、 丁 二$ 二烯、苯乙烯三元共聚合反应规律进 

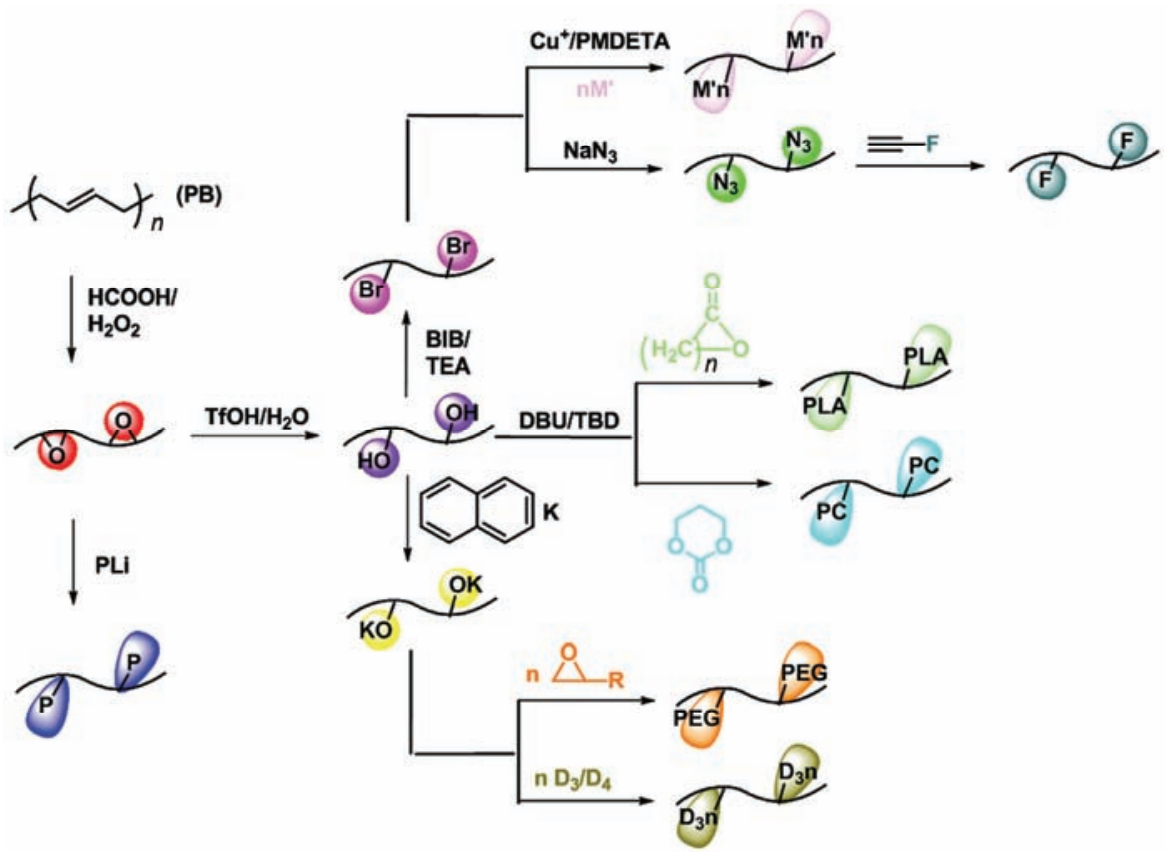

图 3 从环氧基团出发高枝化聚合物的合成方法

Figure 3 Synthesis of dendrigraft polymers based on epoxy group

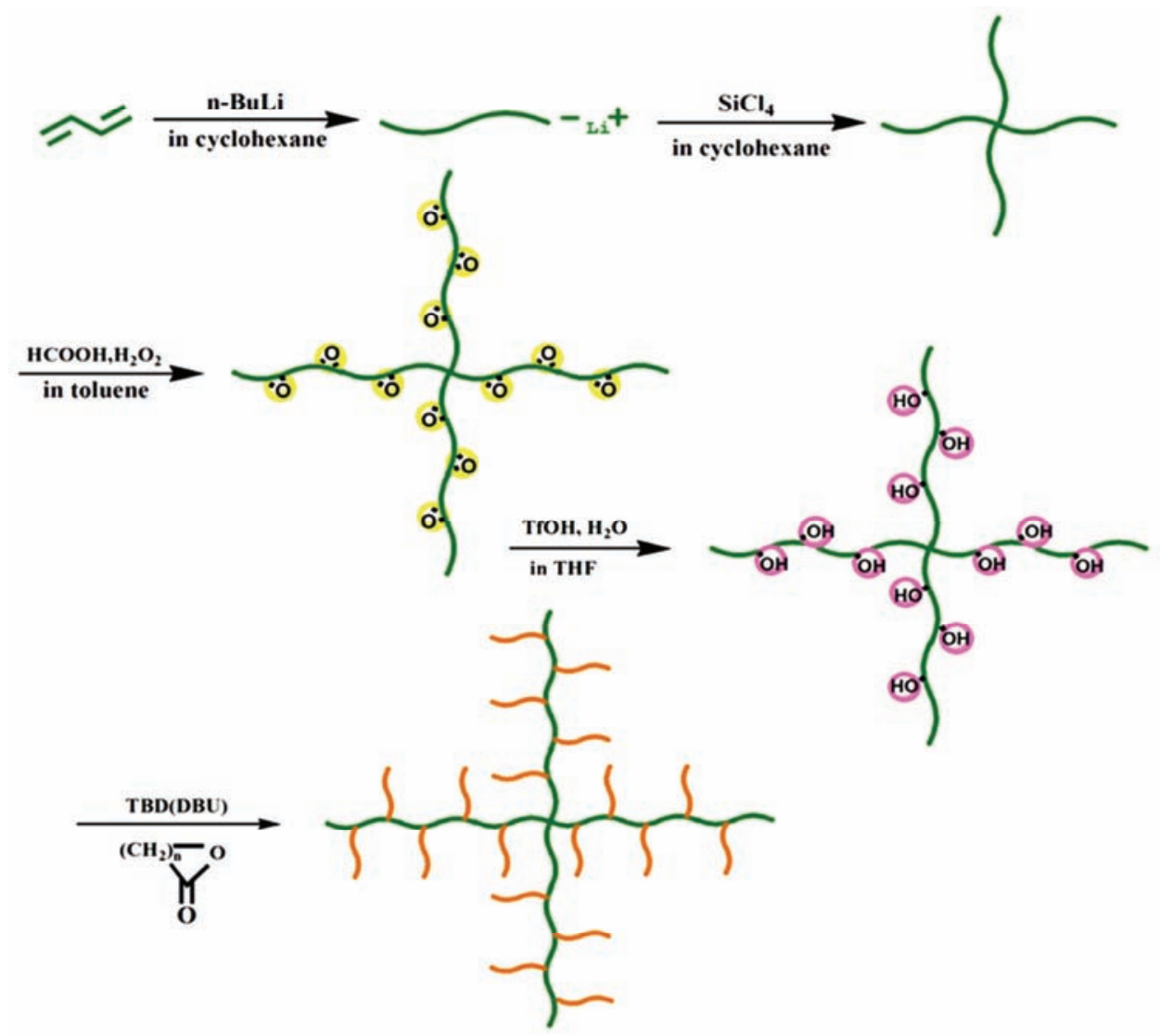

图 4 星形梳状高枝化环内酯开环聚合物合成

Figure 4 Synthesis of dendrigraft star-comb polylactone by ring-opening polymerization 
行了研究. 不同DPE-2N含量的F-SSBR的构效关系研 究结果表明: DPE- $2 \mathrm{~N}$ 的引人有效地提高了碳黑在溶 聚丁苯橡胶中的分散性(图5); 不论是湿法溶液掺混, 还是干法开炼掺混, 与普通丁苯橡胶相比, 碳黑的分 散效果均极大地改善, 结合胶能力显著增强; 有效地 提高了溶聚丁苯橡胶抗湿滑性能、降低了滚动阻

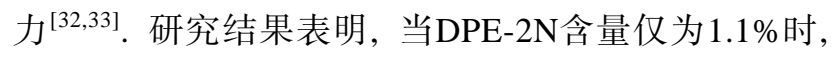
与普通丁苯橡胶相比, $0^{\circ} \mathrm{C}$ 时的 $\tan \delta$ 提高 $30 \%, 60^{\circ} \mathrm{C}$ 时 的 $\tan \delta$ 降低 $29 \%$, 如图6所示 ${ }^{[34]}$. 此外, 本研究组 ${ }^{[35]}$ 采用钪稀土催化体系制备了含有氮基团的高间规聚 苯乙烯.

\section{2 基团转换方法合成官能化聚合物}

聚合物官能团的转换是赋予聚合物新功能的有 效方法, 其中环氧基团是阴离子聚合活性中心的高 效偶联剂, 而将环氧基团转换为差基, 可以得到环状 酯类单体开环聚合的多官能度引发剂; 进一步将羟 基转换为溴基团, 可以得到活性自由基聚合所需的 多官能度引发剂; 再将溴基团转换为叠氮基团后, 又 可以提供点击化学所需的多个反应点. 基团转换不 仅仅是聚合物功能的转变, 也为聚合机理转移反应 提供了丰富的想象空间 ${ }^{[38 \sim 42]}$. 基于机理转移反应, 从活性阴离子聚合到活性自由基聚合, 成功地合成 了高枝化两亲性热熔压敏胶, 主链为油溶性的热熔 压敏胶苯乙烯-异成二烯-苯乙烯共聚物(SIS), 侧链为 水溶性的热熔压敏胶聚丙烯酸酯, 有效地解决了中 医药贴剂组分复杂的问题. 多差基聚合物与烷氧基 金属化合物反应后可生成多官能度烷氧基金属化合 物, 与烷基锂相比, 烷氧基钾等烷氧基金属化合物碱 性较弱, 适用于引发环氧烷烃、硅氧烷烃进行阴离子
开环聚合, 如图3所示. 基于上述方法, 成功地合成 了高枝化环氧乙烷、环氧丙烷的均聚物和共聚物, 环 硅氧烷 D4/D3 的均聚物和共聚物, 两亲性(疏水-亲 水、非晶-结晶)高枝化聚丁二烯/聚环氧乙烷共聚物, 如图7所示 ${ }^{[38,39]}$.

\section{3 硅氢加成方法合成官能化聚合物}

不论是官能化苯乙烯衍生物, 还是官能化 $1,1-二$ 苯基乙烯衍生物, 含有活泼氢的羟基、胺基等官能团 进行活性阴离子聚合时均需要繁琐的保护和解保护 反应, 而往往想要达到较高程度的解保护效率是非 常困难的. 硅氢加成方法是采用Karstedt催化剂(Pt系 催化剂), 通过官能化丙烯衍生物与含有硅氢基团的 聚合物进行硅氢加成反应, 将一系列含有反应性基 团的官能团键入到聚合物链中. 本研究组成功地合 成了硅氢取代型苯乙烯衍生物、硅氢取代型1,1-二苯 基乙烯衍生物单体, 开展了上述两种官能化单体与 丁二烯、异成二烯、苯乙烯共聚合反应规律的探 索 ${ }^{[43 \sim 51]}$, 研究结果表明: 含有 $\mathrm{SiH}$ 基团的 DPE单元 $(\mathrm{DPE}-\mathrm{SiH})$ 在聚合物链中呈现梯度分布; 随着 DPE-SiH用量的增加, 分布呈交替结构, 交替共聚物 的玻璃化转变温度达到 $145^{\circ} \mathrm{C}$. 基于活性阴离子聚合 机理, 在精确控制 $\mathrm{SiH}$ 官能团序列分布的前提下, 合 成了硅氢基团全序列无规分布 $(\mathrm{M}-\mathrm{U})$ 、交替序列分布 (M-A)、梯度序列分布 $(M-G)$ 的梳状聚苯乙烯. 利用一 系列含有液晶基团的官能化丙烯衍生物的成功合成, 开展了硅氢加成反应规律研究, 创制了不同主链结构 的液晶性聚苯乙烯. 与小分子液晶相比, 液晶性聚苯 乙烯具有更宽的液晶相范围，通过改变主链结构可以 实现对液晶性聚合物的液晶相范围进行有效地调控.
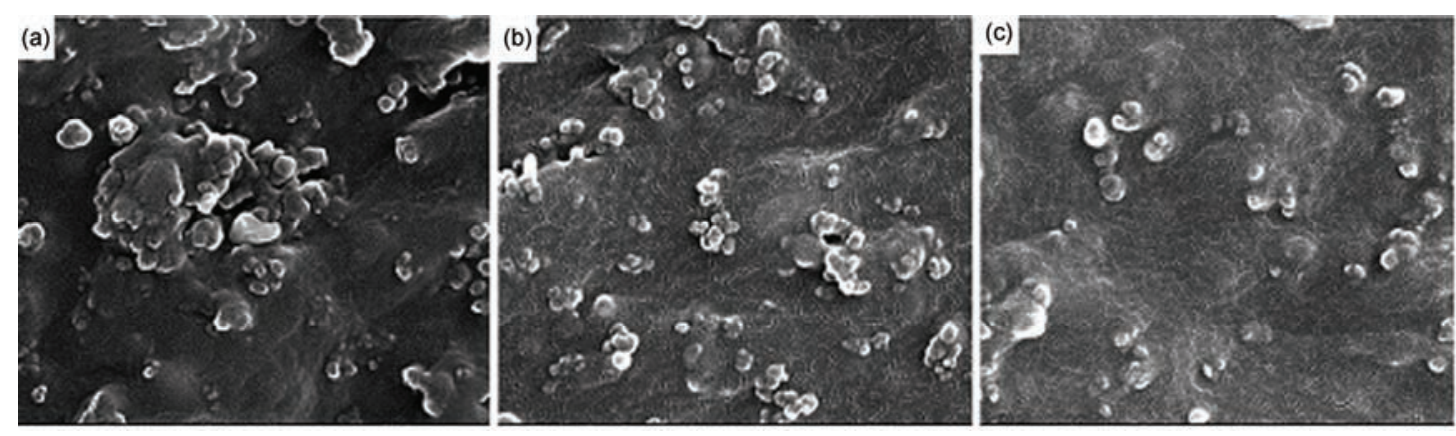

图 5 官能化丁苯橡胶的碳黑分散性(DPE-2N含量: (a) $0 \%$; (b) $0.2 \%$; (c) $1.1 \%$, 炭黑含量: 50 (每一百份中添加的含量) $)^{[33]}$

Figure 5 Dispersion of carbon black in functional butadiene-styrene rubber (DPE-2N content: (a) $0 \%$; (b) $0.2 \%$; (c) $1.1 \%$. Carbon black content: 50 parts perhundred $)^{[33]}$ 


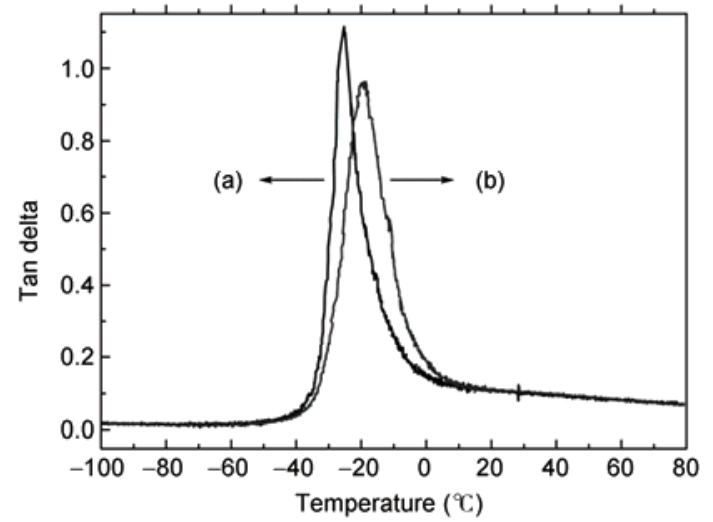

图 6 官能化丁苯橡胶的动态力学性能(DPE-2N含量: (a) $0.2 \%$; (b) $1.1 \%$. 炭黑含量: 50 (每一百份中添加的含量) $)^{[33]}$

Figure 6 Dynamic mechanical properties of functional butadienestyrene rubber (DPE-2N content: (a) $0.2 \%$; (b) $1.1 \%$. Carbon black content: 50 parts perhundred) ${ }^{[33]}$

值得关注的是当主链含有柔性的聚丁二烯、聚异 龙二烯时, 聚合物主链上的硅氢基团不仅可以和官 能化衍生物的端烯基发生加成反应, 而且可以和聚 丁二烯、聚异戊二烯链上的双键发生加成反应, 最终 导致自交联反应发生 ${ }^{[44]}$, 因此主链含有双键的聚合 物难以采用通常的硅氢加成方法实现功能化基团的 键人. 针对以上问题, 设计合成了一系列端硅氢基液 晶性化合物, 基于硅氢加成方法成功地创制了主链 为柔性聚丁二烯基体的具有液晶特性的官能化聚合 物, 揭示了不同支化结构对官能化聚合物液晶性能 的影响规律 ${ }^{[47]}$. 聚丁二烯主链柔顺性好且具有较低 的玻璃化转变温度, 因此它在接枝刚性的侧链液晶 基元后能够获得室温液晶聚合物, 并且高柔性的主 链能够提高聚合物的响应速度. 此外, 聚丁二烯主链 含有可直接功能化的双键, 不需要经过复杂的后处 理, 可以直接接枝液晶基团. 这种合成方法的优势在 于. 首先, 它克服了不完整的后官能化导致 的自交联反应的发生; 其次, 相对简单的硅氢官能化 的液晶小分子的纯化代替了聚合物官能化复杂的提 纯过程; 最后, 聚丁二烯兼具 1,2-悬挂双键和 1,4-主 链双键 2 种单元, 并且通过调控合成方法可制备高乙 烯基和低乙烯基主链的聚丁二烯, 因此采用活性阴 离子聚合方法较易制备拓扑结构的高乙烯基/低乙烯 基含量的高枝化侧链型液晶聚丁二烯, 如图 8 所示. 主链复杂的拓扑结构对聚合物液晶性能的影响规律 的研究结果表明, 与低乙烯基液晶性聚丁二烯相比, 高乙烯基液晶性聚丁二烯具有更宽的液晶相范围;
与星形低乙烯基液晶性聚丁二烯相比，线形低乙烯 基液晶性聚丁二烯具有更宽的液晶相范围; 线形、星 形高乙烯基液晶性聚丁二烯具有不同的织态结构 ${ }^{[47]}$.

\section{4 点击化学法合成官能化聚合物}

与硅氢加成反应相比, 点击化学反应更加高效 快速. 如图3所示, 从多羟基聚丁二烯出发, 差基首 先转换为溴基团、再转换为叠氮基团, 含有多叠氮基 团的线形、星形聚丁二烯与含有端炔基功能性化合物 进行点击化学反应, 得到高枝化官能化聚丁二 烯 ${ }^{[52 ~ 56]}$. 本研究组 ${ }^{[52 ~ 55]}$ 开展了点击化学方法合成官 能化聚合物研究, 完成了端炔基功能性化合物的合 成研究, 其中包括: 端炔基光致变色化合物(端炔基 螺吡喃, SP-Alk)、端炔基苂光化合物(端炔基香豆素, Cou-Alk)的合成; 从线形、星形、线形梳状、星形梳 状聚丁二烯出发, 成功地合成了不同枝化结构的含 有叠氮基团的官能化聚丁二烯, 进而基于点击化学 方法创制了具有光致变色特性、苂光特性的官能化聚 丁二烯, 如图9所示. 不同枝化结构官能化聚丁二烯 的光致变色性能、苂光性能的研究揭示了枝化结构与 光致变色性能、苂光性能之间的构效关系. 结果表明: 对光致变色聚丁二烯而言, 开环时间 $\left(T_{\mathrm{o}}\right)$ 越短, 颜色 变化越快; 闭环时间 $\left(T_{\mathrm{c}}\right)$ 越长, 颜色恢复越慢; 与小 分子螺吡喃相比, 光致变色聚丁二烯的开环时间更 长、闭环时间更短，颜色不易改变、易恢复; 与同代 的星形光致变色聚丁二烯相比, 线形光致变色聚丁 二烯开环时间和闭环时间均更长, 即线形结构的光 致变色聚丁二烯颜色不易改变、不易恢复; 随着代数 增加, 线形和星形光致变色聚丁二烯的开环时间变 长、闭环时间变短, 即高代的光致变色聚丁二烯颜色 不易改变、易恢复. 对苂光聚丁二烯而言，与小分子 香豆素相比, 苂光聚丁二烯的苂光强度和苂光量子 产率更高; 与同代星形苂光聚丁二烯相比, 线形苂光 聚丁二烯的苂光强度和苂光量子产率均更高; 随着 代数的增加, 线形和星形苂光聚丁二烯的苂光强度 和苂光量子产率均减小.

\section{3 小结}

基于活性阴离子聚合理论和方法，从环氧基团 出发可构建一系列线形梳状和星形梳状高枝化聚合 物合成方法平台, 并可用于创制一系列以高枝化锂 系聚合物为代表的高性能高分子材料. 基于不同结 


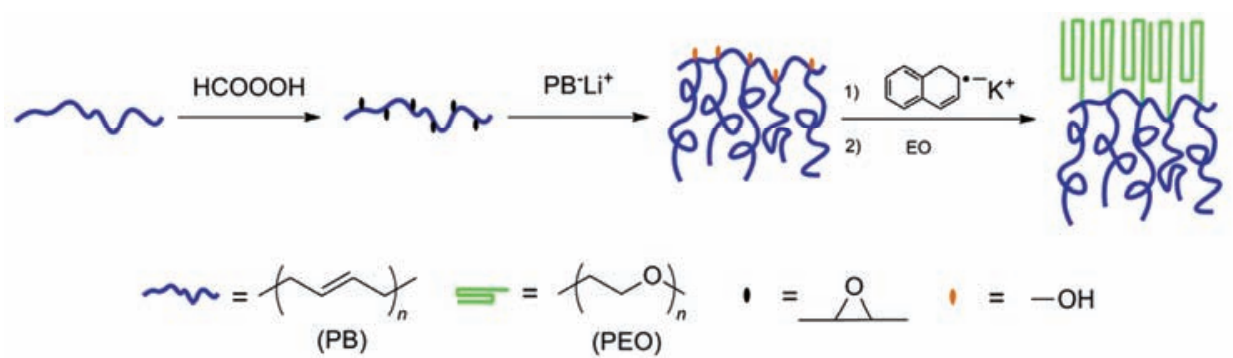

图 7 两亲性高枝化 $\mathrm{PB} / \mathrm{PEO}$ 聚合物

Figure 7 Amphipathy dendrigraft PB/PEO polymer

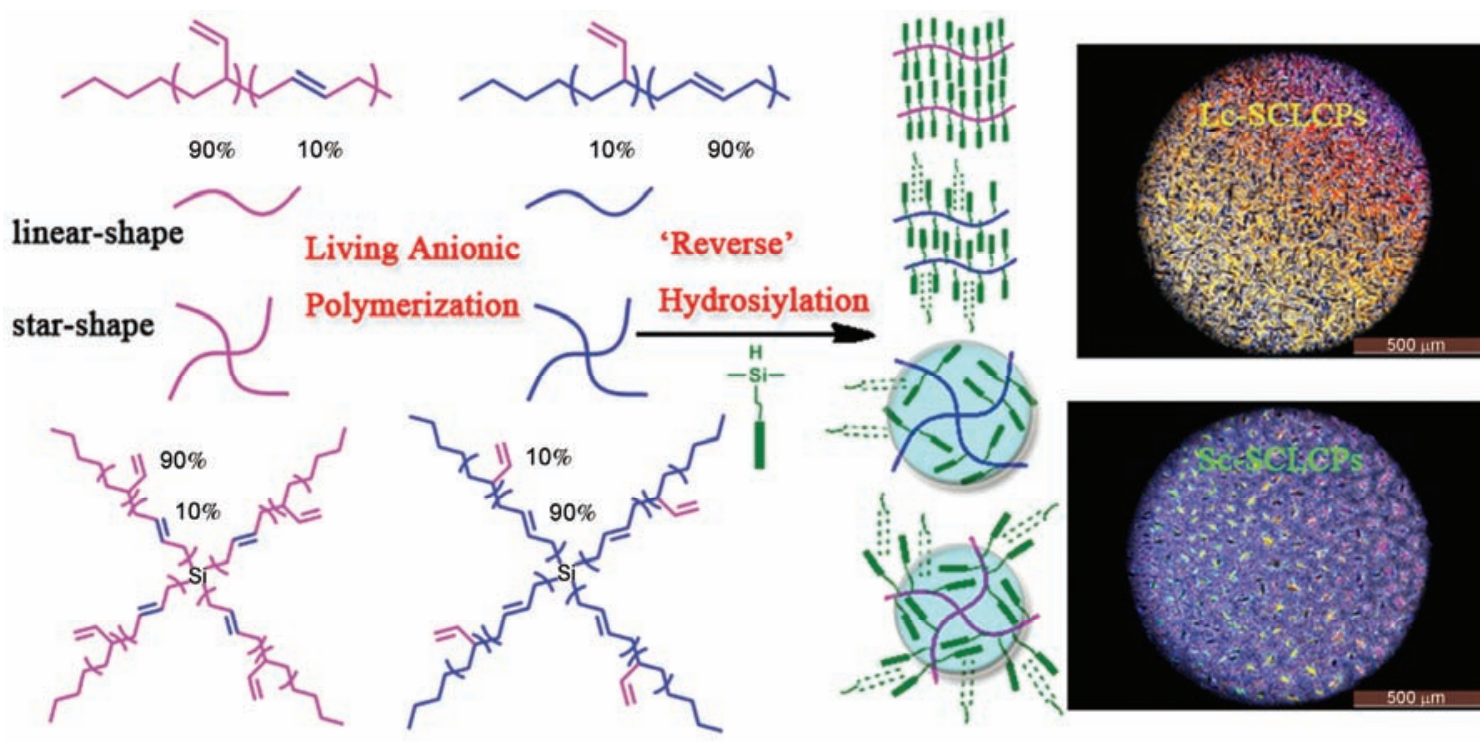

图 8 低乙烯基、高乙烯基含量的液晶性聚丁二烯 ${ }^{[47]}$

Figure 8 Liquid crystalline polymer with low and high vinyl content ${ }^{[47]}$

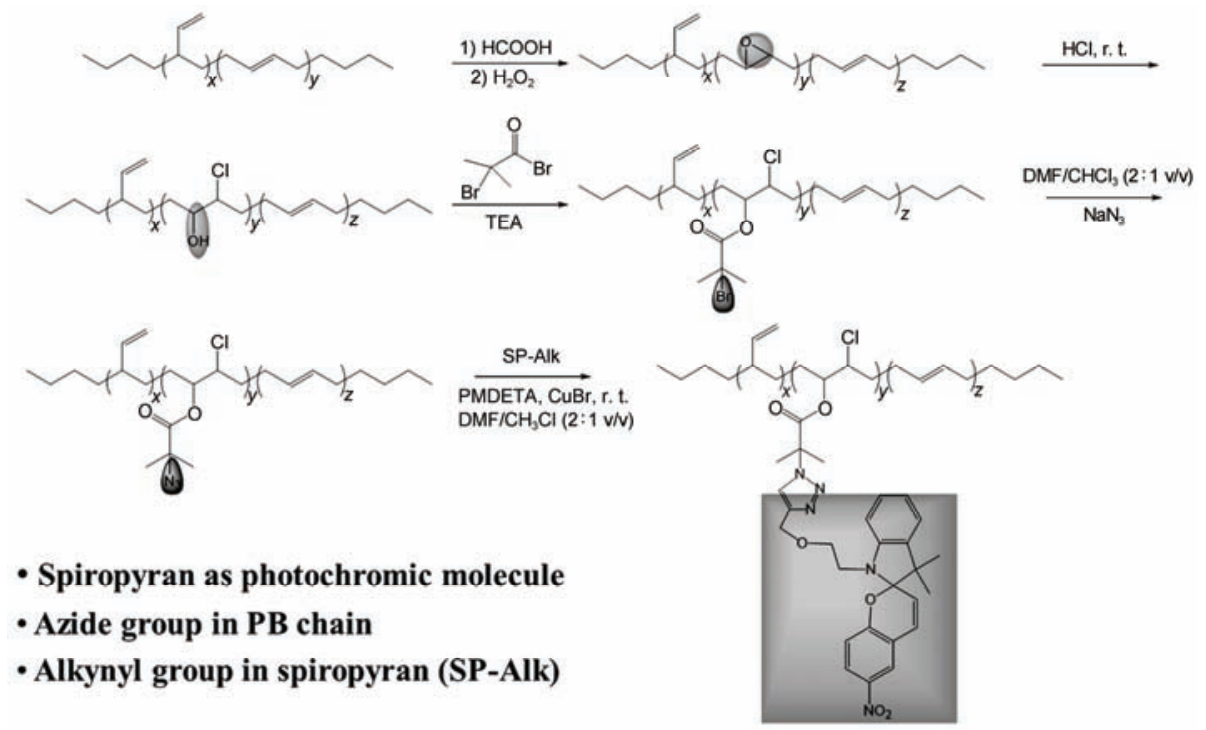

图 9 点击化学法合成光致变色聚丁二烯

Figure 9 Synthesis of photochromic polybutadiene with click chemistry 
构的环氧化聚丁二烯/聚异戊二烯, 以环氧基团为基 础, 采用环氧化-偶联反应循环迭代增长的方法可制 备结构新渘的多代线形梳状和星形梳状高枝化聚合 物, 用于构筑简便高效的高枝化聚合物精确合成方 法平台. 以实现链中功能聚合物“定性、定位、定量” 为目标, 设计开发先进的活性阴离子聚合高真空实 验技术, 通过共聚合反应方法、基团转换方法、硅氢 加成方法、点击化学方法将目标功能性基团键人到聚 合物链中, 系统地研究了具有复杂拓扑结构的链中 官能化高枝化聚合物的精确合成方法以及结构与性 能之间的构效关系. 设计合成了一系列官能化DPE 衍生物, 建立了具有复杂结构的官能化DPE衍生物 合成、分离精制方法, 揭示了具有不同官能团的DPE 衍生物与丁二烯、异戊二烯、苯乙烯共聚合反应规律. 设计合成了一系列端烯基液晶性大分子, 基于硅氢 加成反应, 合成了高枝化液晶性聚苯乙烯; 设计合成 了一系列端硅氢基液晶性大分子、高枝化液晶性聚丁 二烯/聚异戊二烯, 创新性地解决了传统硅氢加成反
应过程中的自交联反应瓶颈; 揭示了复杂拓扑结构 对高枝化液晶性聚合物的液晶性能的影响规律. 此 外，设计合成的苂光化合物端炔基香豆素、光致变色 化合物端炔基螺吡喃，基于点击化学反应可用于合 成高枝化苂光聚丁二烯、光致变色聚丁二烯, 该结果 揭示了复杂拓扑结构对高枝化苂光聚合物的苂光性 能、光致变色聚合物的光致变色性能的影响规律. 液 晶聚丁二烯、高枝化苂光聚丁二烯和光致变色聚丁二 烯均以聚丁二烯为主链, 通过原位引人官能化基团 的方法, 扩展并延伸了聚丁二烯橡胶的性能, 为合成 绿色轮胎橡胶提供了新思路、新方法. 以上聚合物性 能的考察也为进一步合成绿色轮胎橡胶提供了实验 依据和基础. 综上, 本研究组成功地构建了高枝化功 能聚合物合成方法平台，基于共聚合方法、基团转换 方法、硅氢加成方法、点击化学方法创制了一系列高 枝化功能聚合物, 揭示了功能聚合物的高枝化拓扑 结构与性能之间的关联规律, 为高枝化功能聚合物 的设计开发提供了依据.

\section{参考文献}

1 Quirk R P, Yoo T, Loo Y, et al. Applications of 1,1-diphenylethylene chemistry in anionic synthesis of polymers with controlled structures. Adv Polym Sci, 2000, 153: 67-162

2 Hirao A, Loykulnant S, Ishizone T. Recent advance in living anionic polymerization of functionalized styrene derivatives. Prog Polym Sci, 2002, 27: 1399-1471

3 Hirao A, Hayashi M, Loykulnant S, et al. Precise syntheses of chain-multi-functionalized polymers, star-branched polymers, star-linear block polymers, densely branched polymers, and dendritic branched polymers based on iterative approach using functionalized 1,1-diphenylethylene derivatives. Prog Polym Sci, 2005, 30: 111-182

4 Nikos H, Stergios P, Marinos P, et al. Asymmetric star polymers: Synthesis and properties. Adv Polym Sci, 1999, 142: 71-127

5 Tsoukatos T, Pispas S, Hadjichristidis N. Complex macromolecular architectures by combing TEMPO living free radical and anionic polymerization. Macromolecules, 2000, 33: 9504-9511

6 Yuan Z, Gauthier M. Synthesis of arborescent isoprene homopolymers. Macromolecules, 2005, 38: 4124-4132

7 Astruc D, Boisselier E, Ornelas C. Dendrimers designed for functions: From physical, photophysical, and supramolecular properties to applications in sensing, catalysis, molecular electronics, photonics, and nanomedicine. Chem Rev, 2010, 110: 1857-1959

8 Ma H, Zhang C, Li Y, et al. Study and modification of high vacuum technique used for living anionic polymerization (in Chinese). Acta Polym Sin, 2011, 12: 1390-1394 [马红卫, 张春庆, 李杨, 等. 应用于活性负离子聚合的高真空实验技术研究和改进. 高分子学报, 2011, 12: 1390-1394]

9 Ma H W, Li Y, Zhang C Q, et al. Progress in studies on the methodologies of living anionic polymerization using high vacuum technique (in Chinese). Polym Bull, 2011, 9: 35-51 [马红卫, 李杨, 张春庆, 等. 基于高真空实验技术活性阴离子聚合方法学研究进展. 高分 子通报, 2011, 9: 35-51]

10 Zhang Y, Li Y, Li C, et al. Recent developments of the dendrigraft polymers (in Chinese). Polym Bull, 2011, 9: 81-91 [张宇, 李杨, 李 灿, 等. 高枝化聚合物的最新研究进展. 高分子通报, 2011, 9: 81-91]

11 Li Y, Wang Y S, Shen K H, et al. Methodology of synthesis of dendrigraft and in-chain functionalized polymers (in Chinese). Polym Bull, 2014, 5: 88-97 [李杨, 王艳色, 申凯华, 等, 链中功能性高枝化聚合物的合成方法. 高分子通报, 2014, 5: 88-97]

12 Gauthier M, Moller M. Uniform highly branched polymers by anionic grafting: Arborescent graft polymers. Macromolecules, 1991, 24: $4548-4553$ 
13 Li J, Gauthier M. A novel synthetic path to arborescent graft polystyrene. Macrmolecules, 2001, 34: 8918-8924

14 Hempenius M A, Michelberger W, Moller M. Arborescent graft polybutadienes. Macromolecules, 1997, 30: 5602-5605

15 Yuan Z, Gauthier M. Synthesis of arborescent isoprene homopolymers. Macromolecules, 2005, 38: 4124-4132

16 Zhang $\mathrm{H}$, Li Y, Zhang C, et al. Synthesis of dendrigraft star-comb polybutadiene by anionic polymerization and grafting-onto methodology. Macromolecules, 2009, 42: 5073-5079

17 Zhang H, Li Y, Zhang C, et al. Synthesis and characterization of star-comb polybutadiene and poly(ethylene-co-butene). Chin Chem Lett, 2010, 21: 361-364

18 Zhang Q, Chen C, Zhang H, et al. Synthesis and characterization of star-comb styrene/butadiene copolymer. Chin Chem Lett, 2010, 21: $1370-1373$

19 Sang W, Ma H, Wang Q, et al. Preparation of functionalized precursor of SiC ceramic via hydrosilylation polymerization of 1,1-diphenylethylene derivatives. Des Monomers Polym, 2015, 18: 479-485

20 Chen C. Study on highly transparent and high impact styrene/butadiene copolymers (in Chinese). Master Dissertation. Dalian: Dalian University of Technology, 2009 [陈闯. 高透明抗冲击苯乙烯/丁二烯共聚物的研究. 硕士学位论文. 大连: 大连理工大学, 2009]

21 Li X. Synthesis of star-comb hyperbranched polyisoprene (in Chinese). Master Dissertation. Dalian: Dalian University of Technology, 2009 [李欣. 星形梳状超支化聚异戊二烯的合成. 硕士学位论文. 大连: 大连理工大学, 2009]

22 Zhang H X. Study on butadiene/isoprene/styrene star-comb dendrigraft polymer (in Chinese). Doctor Dissertation. Dalian: Dalian University of Technology, 2010 [张红霞. 丁二烯/异戊二烯/苯乙烯星形梳状高支化聚合物的研究. 博士学位论文. 大连: 大连理工大 学, 2010]

23 Li Y, Zhang C Q, Zhang H X, et al. Star-comb butadiene/isoprene/styrene polymer and their preparation (in Chinese). PRC Patent, ZL 200710157403.7, 2010-11-10 [李杨, 张春庆, 张红霞, 等. 中国专利, ZL 200710157403.7, 2010-11-10]

$24 \mathrm{Li} \mathrm{Y,} \mathrm{Li} \mathrm{Z} \mathrm{S,} \mathrm{Zhang} \mathrm{H} \mathrm{X,} \mathrm{et} \mathrm{al.} \mathrm{Star-comb} \mathrm{butadiene/styrene} \mathrm{block} \mathrm{copolymer} \mathrm{and} \mathrm{their} \mathrm{preparation} \mathrm{(in} \mathrm{Chinese).} \mathrm{PRC} \mathrm{Patent,} \mathrm{ZL}$ 200810190932.1, 2010-12-22 [李杨, 李战胜, 张红霞, 等. 中国专利, ZL 200810190932.1, 2010-12-22]

25 Leng X, Wei Z, Ren Y, et al. Facile synthesis and comparative study of poly(L-lactide) with linear-comb and star-comb architecture. RSC Adv, 2015, 5: 81482-81491

26 Ren Y, Gao Q, Zhou C, et al. Facile synthesis of well-defined linear-comb highly branched poly(epsilon-caprolactone) using hydroxylated polybutadiene and organocatalyst. RSC Adv, 2015, 5: 27421-27430

27 Ren Y, Wei Z, Leng X, et al. Boric acid as biocatalyst for living ring-opening polymerization of epsilon-caprolactone. Polymer, 2015, 78: $51-58$

28 Li Y, Leng X F, Shen K H, et al. Linear-comb polylactide and their preparation (in Chinese). PRC Patent, ZL 201210428685.0, 2015-04-08 [李杨, 冷雪菲, 申凯华, 等. 中国专利, ZL 201210428685.0, 2015-04-08]

29 Li Y, Leng X F, Shen K H, et al. Star-comb polylactide and their preparation (in Chinese). PRC Patent, ZL 201310064475.2, 2015-02-18 [李杨, 冷雪菲, 申凯华, 等. 中国专利, ZL 201310064475.2, 2015-02-18]

30 Pispas S, Hadjichristidis N. Aggregation behavior of poly(butadiene-b-ehtylene oxide) block copolymers in dilute aqueous solutions: Effect of concentration temperature, ionic strength, and type of surfactant. Langmuir, 2003, 19: 48-54

31 Yamada M, Hirao A, Nakahama S, et al. Synthesis of side-chain liquid crystalline homopolymers and block copolymers with well-defined structures by living anionic polymerization and their thermotropic phase behavior. Macromolecules, 1995, 28: 50-58

32 Wu L, Wang Y, Wang Y, et al. In-chain multi-functionalized polystyrene by living anionic copolymerization with 1,1-bis (4-dimethylaminophenyl)ethylene: Synthesis and effect on the dispersity of carbon black in polymer-based composites. Polymer, 2013, 54: 2958-2965

33 Wu L, Ma H, Wang Q, et al. In-chain multi-functionalized random butadiene-styrene copolymer via anionic copolymerization with 1,1bis(4-dimethylaminophenyl)ethylene: Synthesis and its application as a rubber matrix of carbon black-based composite. J Mater Sci, 2014, 49: 5171-5181

34 Wu L, Ma H, Lu X, et al. Synthesis and thermal analysis of in-chain multi-functionalized polybutadiene using 1,1-bis (4-dimethylaminophenyl)ethylene. J Macromol Sci Part A Pure Appl Chem, 2014, 51: 27-32

35 Shi Z, Guo F, Li Y, et al. Synthesis of amino-containing syndiotactic polystyrene as efficient polymer support for palladium nanoparticles. J Polym Sci Part A Polym Chem, 2015, 53: 5-9

36 Ding J. Anionic synthesis of in-chain multi-functionalized copolymers with precise molecular architectures (in Chinese). Master Dissertation. Dalian: Dalian University of Technology, 2012 [丁君. 活性阴离子方法精确合成链中多功能化共聚物. 硕士学位论文. 大连: 大连理工大学, 2012]

37 Wu L L. Study on dimethylamino in-chain multi-functionalized butadiene/styrene polymers (in Chinese). Doctor Dissertation. Dalian: Dalian University of Technology, 2014 [吴玲玲. 二甲胺基链中多官能化丁二烯/苯乙烯聚合物研究. 博士学位论文. 大连: 大连理 工大学, 2014] 
38 Gao Q, Wang Y, Ren Y, et al. Facile synthesis of amphiphilic heterografted copolymers with crystallin and amophous side chains. Macromol Chem Phys, 2013, 214: 1677-1687

39 Gao Q, Wang Y, Ren Y, et al. Novel dual-grafted copolymer bearing galssy polystyrene and crystallin poly(ethylene oxide) as side chians. J Macromol Sci Part A Pure Appl Chem, 2013, 50: 1157-1165

40 Gao Q, Ren Y, Li Y. Synthesis of low molecular distribution dihydric polybutadiene in the presence of triflic acid. J Macromol Sci Part A: Pure Appl Chem, 2013, 50: 297-301

41 Gao Q. Study on linear/star amphiphilic dual-grafted copolymers (in Chinese). Doctor Dissertation. Dalian: Dalian University of Technology, 2013 [高清. 线形/星形两亲性双接枝聚合物的研究. 博士学位论文. 大连: 大连理工大学, 2013]

42 Zhang Y, Shen K H, Wang Y S, et al. Synthesis of star-comb copolymer PB-g-PMMA by mechanism transformation (in Chinese). Acta Polym Sin, 2013, 2: 216-223 [张宇, 申凯华, 王艳色, 等. 机理转移法合成星形梳状聚丁二烯- $g$-聚甲基丙烯酸甲酯共聚物的研究. 高分子学报, 2013, 2: 216-223]

43 Wang B, Ma H, Wang Y, et al. Synthesis and characterization of novel liquid crystalline polystyrene. Chem Lett, 2013, 42: 915-917

44 Wang B, Ma H, Shen K, et al. Synthesis and characterization of in-chain silyl-hydride functional SBR and self-crosslinking elastomer. Chin Chem Lett, 2012, 23: 1419-1422

45 Ding J, Li Y, Shen K, et al. Anionic synthesis of binary random in-chain multi-functionalized poly(styrene/butadiene/isoprene) and dimethyl [4-phenylvinyl-phenyl]silane)(PS-DPESiH, PB-DPESiH, PI-DPESiH) copolymers. Chin Chem Lett, 2012, 23: 749-752

$46 \mathrm{Ma} \mathrm{H}$, Wang B, Zhang C, et al. Synthesis and characterization of poly[(4-cinylphenyl)dimethylsilane]- $b$-polybutadiene-b-poly[(4vinylphenyl)dimethylsilane](PVPDMS- $b$-PBd- $b$-PVPDMS). Chin Chem Lett, 2011, 22: 1371-1374

47 Han L, Ma H, Li Y, et al. Construction of topological macromolecular side chains packing model: Study unique relationship and differences in LC-microstructures and properties of two analogous architectures with well-designed side attachment density. Macromolecules, 2015, 48: 925-941

48 Ma H, Wang Q, Sang W, et al. Synthesis of bottlebrush polystyrene with uniform, alternating, and gradient distributions of brushes via living anionic polymerization and hydrosilylation. Macromol Rapid Commun, 2015, 36: 726-732

49 Ma H, Wang Q, Sang W, et al. Facile synthesis of dendrimac polymers via the combination of living anionic polymerization and highly efficient coupling reactions. Macromol Rapid Commun, 2016, 37: 168-173

50 Sang W, Ma H, Wang Q, et al. Monomer sequence determination in the living anionic copolymerization of styrene and asymmetric bi-functionalized 1,1-diphenylethylene derivatives. Polym Chem, 2016, 7: 219-234

51 Wang B. Studies on the side chain liquid crystal polymers synthesized from poly(4-vinylphenyldimethylsilane) (in Chinese). Doctor Dissertation. Dalian: Dalian University of Technology, 2014 [王柏. 二甲胺基链中多官能化丁二烯/苯乙烯聚合物研究. 博士学位论 文. 大连: 大连理工大学, 2014]

52 Zhang Y, Shen K, Guo F, et al. Incorporation of chromophores into dendrigraft polybutadiene: Effect of dendrograft matrix on the fluorescent properties. RSC Adv, 2013, 3: 20345-20352

53 Zhang Y, Guo F, Shen K, et al. Dendritic effects on photophysical and fluorescence properties of coumarin functionalized dendrigraft polybutadiene. Polymer, 2014, 55: 1202-1208

54 Zhang Y, Yu T, Zhang Y, et al. Effect of dendritic architecture on photochromism of spiropyran functionalized dendrigraft polybutadiene. Adv Mater Res, 2014, 884-885: 51-54

55 Zhang Y. Study on chromophore functionalized linear-comb/star-comb dendrigraft polybutadiene (in Chinese). Doctor Dissertation. Dalian: Dalian University of Technology, 2014 [张宇. 含光敏基团线形梳状/星形梳状高支化聚丁二烯研究. 博士学位论文. 大连：大 连理工大学, 2014]

56 Zhang Y. The synthesis of colored resin for color toner via combination of NMRP and "click" chemistry (in Chinese). Master Dissertation. Dalian: Dalian University of Technology, 2015 [张岩. NMRP 与点击化学联用合成彩色碳粉用有色树脂. 硕士学位论文. 大连: 大连理工大学, 2015] 


\title{
Synthesis methodology of dendrigraft functional polymer
}

\author{
LI TingTing, MA HongWei, WEI ZhiYong, GUO Fang, SHEN KaiHua, NIU Hui \& LI Yang \\ State Key Laboratory of Fine Chemicals, Department of Polymer Science and Engineering, Dalian University of Technology, Dalian 116024, China
}

Structuralization, functionalization and integration are efficient pathways to improve the properties of synthetic rubber and elastomer, and the living anionic polymerization is an effective method to prepare polymer chain with topological structure and functional groups. Recently, the dendrigraft polymers attracted more and more attentions in the macromolecular chemistry, owing to their unique structure and properties. Herein, the synthesis methodology of dendrigraft functional polymers was summarized. On the basis of epoxidized polybutadiene/polyisoprene with different structures, novel dendrigraft star-comb polymers were precisely synthesized by the iterative epoxidation-coupling reactions with coupling groups in the polymer chain. High vacuum technique in the living anionic polymerization was explored, establishing the efficient synthesis strategy for the preparation of dendrigraft star-comb polymers. Aiming to achieve in-chain functionalized polymers with the goal of "definite function", "accurate quantity" and "precise position", the precise synthesis of in-chain functional polymers with complex topological structure was researched and the relationship between the polymer structure and performance was probed. These dendrigraft functional polymers were prepared by introducing different target functionalized groups into polymer chain via copolymerization, group transfer reaction, hydrosilylation and click chemistry. A series of functionalized DPE derivatives with complex structures were designed and the corresponding synthesis pathway and purification method for the monomers were examined. The copolymerization of DPE derivatives possessing different functional groups with butadiene, isoprene and styrene were also illustrated. Based on the synthesis of a series of liquid crystal macromolecules with alkenyl-teminated units, dendrigraft liquid crystal polystyrene was prepared with hydrosilylation reactions. Based on the synthesis of a series liquid crystal macromolecules with $\mathrm{SiH}$-teminated units, the dendrigraft liquid crystal polybutadiene/polyisoprene were prepared, resolving the difficulty caused by the self-crosslinking reaction in the polymerization of functionalized conjugated dienes with hydrosilylation reaction. This work illustrated the influences of topological structure toward the liquid crystal properties of the dendrigraft polymers. Based on the preparation fluorescent compounds (alkynyl-teminated coumarin) and photochromic compounds (alkynyl-teminated spiropyrane), fluorescent polybutadiene and photochromic polybutadiene with dendrigraft topology were obtained by click chemistry, respectively. This work demonstrated the influences of complex topological structure toward the fluorescence and photochromism characteristics of the dendrigraft polymers. With copolymerization, group transfer reaction, hydrosilylation and click chemistry, dendrigraft functional polymers with polybutadiene main chain were attained, which expanded the characteristic of rubber and proposed the novel pathway for green rubber synthesis. The green rubber could be further designed based on the revealed relationship between topological structure and properties within functional polymers.

dendrigraft polymers, functionalization, anionic polymerization, synthesis methodology

doi: 10.1360/N972015-01152 